Supplement of Geosci. Commun., 3, 279-290, 2020

https://doi.org/10.5194/gc-3-279-2020-supplement

(C) Author(s) 2020. This work is distributed under

the Creative Commons Attribution 4.0 License.

(c) (1)

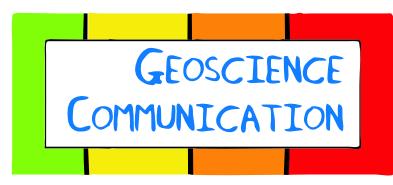

Supplement of

\title{
Impact of an educational program on earthquake awareness and preparedness in Nepal
}

Shiba Subedi et al.

Correspondence to: Shiba Subedi (shiba.subedi@unil.ch)

The copyright of individual parts of the supplement might differ from the CC BY 4.0 License. 


\begin{tabular}{|c|c|c|c|c|c|}
\hline Q.N. & Questions & $\begin{array}{l}\text { Observed } \\
\chi^{2} \text { Value }\end{array}$ & $\begin{array}{l}\text { Threshold } \\
\chi^{2} \text { Value }\end{array}$ & p-value & Remarks \\
\hline Q1 & $\begin{array}{l}\text { In your opinion, what should be the cause of an } \\
\text { earthquake? }\end{array}$ & 78.15 & 7.81 & $<0.00001$ & \multirow{10}{*}{$\begin{array}{l}\text { Null } \\
\text { hypothesis } \\
\text { rejected }\end{array}$} \\
\hline Q3 & $\begin{array}{l}\text { What do you think, how likely is the occurrence of an } \\
\text { earthquake in Nepal greater than the magnitude of } 2015 \\
\text { Gorkha earthquake in your life? }\end{array}$ & 43.59 & 9.49 & $<0.00001$ & \\
\hline Q4 & $\begin{array}{l}\text { What do you think, can your house building resist a large } \\
\text { earthquake? }\end{array}$ & 10.30 & 5.99 & 0.005 & \\
\hline Q5 & $\begin{array}{l}\text { Do all the members of your family know exactly what to } \\
\text { do and where to go at the time of an earthquake? }\end{array}$ & 32.96 & 5.99 & $<0.00001$ & \\
\hline Q6 & $\begin{array}{l}\text { Do you know you should not call others after an event, to } \\
\text { leave the lines available for rescue operations? }\end{array}$ & 138.72 & 3.84 & $<0.00001$ & \\
\hline Q7 & $\begin{array}{l}\text { If a large earthquake occurred at night, could you save } \\
\text { yourself? }\end{array}$ & 37.65 & 3.84 & $<0.00001$ & \\
\hline Q8 & $\begin{array}{l}\text { Do you know that the majority of all injuries that occur in } \\
\text { earthquakes are caused by people being hit by or } \\
\text { stumbling over fallen objects such as furniture, glassware, } \\
\text { appliances and pictures on the walls? }\end{array}$ & 44.16 & 3.84 & $<0.00001$ & \\
\hline Q9 & $\begin{array}{l}\text { Do you know that earthquakes can make additional } \\
\text { damage such as fire, landslides, floods? }\end{array}$ & 7.33 & 5.99 & 0.025 & \\
\hline Q10 & $\begin{array}{l}\text { What do you think the level of risk for an earthquake is in } \\
\text { your city? }\end{array}$ & 6.33 & 5.99 & 0.042 & \\
\hline Q11 & $\begin{array}{l}\text { The preparedness for a major earthquake is the most } \\
\text { important thing. Are you regularly discussing this topic } \\
\text { with your family? }\end{array}$ & 27.70 & 3.84 & $<0.00001$ & \\
\hline Q12 & $\begin{array}{l}\text { Are you interested to know more about earthquakes and } \\
\text { preparedness in details? }\end{array}$ & 0.016 & 3.84 & 0.899 & $\begin{array}{l}\text { Null } \\
\text { hypothesis } \\
\text { accepted }\end{array}$ \\
\hline
\end{tabular}

Supplementary Table 1: Summary of questions asked in the 2018 and 2020 surveys, followed by statistical indices of change in 2 years of our program: the corresponding calculated and tabulated chi-square values, and p-values at 0.05 significance level. 


\section{Survey for Students: under the framework of Seismology - at - School in Nepal Program}

Nepal lies in a very active seismic zone and we are motivated to do work for earthquake education and better preparedness. This survey is carried out to understand the knowledge of local people's awareness regarding earthquake from a particular area. Please answer the following questions based on your personal experience. If you are uncertain, ask the interviewer(s).

Questions only for the survey before initiation of our program

a. Did you feel the earthquake that happened in 2015?
a. $\square$ Yes
b. $\square$ No

b. What did you feel / experience? (multiple choice)
a. $\square$ shaking of the ground
b. $\square$ rattling of the glass
c. $\square$ moving of the furniture
d. $\square$ swinging of the lights
e. $\square$ light damage to structures
f. $\square$ severe
g. $\square$ Other (please specify)

c. What did you do?
a. $\quad \square$ I ran out of the building
b. $\square$ I hid under the table
c. $\square$ I stood next to the wall, or under the doorframe
d. $\square$ I froze / didn't know what to do
e. $\square$ Other (please specify)

d. How did you feel?
a. $\square$ I was calm
b. $\square$ I was scared
c. $\square$ I panicked
d. $\square$ I didn't care
e. $\square$ Other (please specify)

Questions for both surveys before and after the initiation of our program

Q 1. In your opinion, what should be the cause of an earthquake?
a. $\square$ Moving earth
b. $\square$ Plate tectonics
c. $\square$ Energy beneath earth
d. $\square$ Role of Fish
e. $\square$ Other (please specify)

Q 2. What could be your condition, if there was an earthquake of $M>8.0$ as according to the scientists around the world? (multiple choice)
a. $\square$ I could get hurt
b. $\quad \square$ I could be buried alive
c. $\square$ My home could collapse
d. $\square$ I could lose the people I love
e. $\square$ I could die
f. $\square$ Other (please specify)

Q 3. What do you think, how likely is the occurrence of an earthquake larger than Gorkha in your life?
a. $\square$ Impossible $(0 \%)$
b. $\square$ Very unlikely $(10 \%)$
c. $\square$ Unlikely $(30 \%)$
d. $\square$ Likely $(70 \%)$
e. $\square$ Most likely $(90 \%)$ 
Q 4. What do you think your house building can resist the large earthquake?

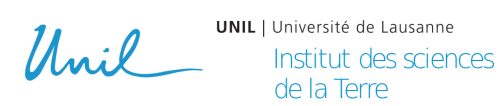
a. $\square$ Yes
b. $\square$ No
c. $\square$ I don't know

Q 5. Do all the members of your family know exactly what to do and where to go at the time of an earthquake?
a. $\square$ Yes
b. $\square$ No
c. $\square$ Partially

Q 6. Do you know you should not call others after an event, to leave the lines available for rescue operations?
a. $\square$ Yes
b. $\square$ No

Q 7. If a large earthquake occurred at night, could you save yourself?
a. $\square$ Yes
b. $\square$ No

Q 8. Do you know that majority of all injuries that occur in earthquakes are caused by people being hit by or stumbling over fallen objects such as furniture, glassware, appliances and pictures on the walls?
a. $\square$ Yes
b. $\square$ No

Q 9. Do you know that earthquakes can make additional damage like as fire, landslides, floods?
a. $\square$ Yes
b. $\square$ No
c. $\square$ Partially

Q 10. What do you think the level of risk for an big earthquake in your city?
a. $\square$ High
b. $\square$ Medium
c. $\square$ Low

Q 11. The preparedness for a major earthquake is the most important thing. Are you regularly discussing this topic with your family?
a. $\square$ Yes
b. $\square$ No

Q 12. Are you interested to know about an earthquake and preparedness in details?
a. $\square$ Yes
b. $\square$ No

Q 13. Earthquake-related knowledge (multiple choice)
a. $\square \mathrm{I}$ know when an earthquake will occur
b. $\square$ I know earthquake cannot be prevented
c. $\square$ I have participated in disaster risk education training or workshop

Q 14. Earthquake preparedness (multiple choice)
a. $\quad \square$ I think to come across an earthquake and remain alive depends on our luck
b. $\square$ I know the importance of disseminating experiences or knowledge of earthquake
c. $\square$ I know the government will provide enough facilities after an earthquake and we will not face problem
d. $\square$ I am confident for reconstruction activities from the government after a disaster
e. $\square$ I know the importance of talking about disasters with neighbours, friends and colleagues

Q 15. Earthquake adaptations (multiple choice)
a. $\square$ I am aware of the shelter areas and open space where you can evacuate/run in case of an earthquake
b. $\square$ I have information about which government office needs to be contacted after an earthquake
c. $\square$ I have knowledge about earthquake prone area
d. $\square$ I am getting enough information from $\mathrm{INGO} / \mathrm{NGO}$ about disaster adaptation
e. $\square$ I have knowledge about an evacuation area during an earthquake 
e. Do you discuss with the people around you in the community to share your knowledge on earthquakes that you learned in school?
a. $\quad \square$ Yes, with many people
b. $\square$ Yes, with some people
c. $\square$ Yes, only with parents
d. $\square$ Not at all

f. Do you know there is seismometer installed in your school?
a. $\square$ Yes
b. $\square$ No

g. How do you observe waveforms recorded by the seismometer?
a. $\square$ On computer in school
b. $\square$ On my mobile
c. $\square$ On teacher's mobile
d. $\square$ On parent's mobile
e. $\square$ I don't see waveforms

h. How often do teachers teach about earthquake?
a. $\square$ Once in a week
b. $\square$ Once in a month
c. $\square$ When earthquake happens
d. $\square$ When I asked to teacher
e. $\square$ Not regularly

i. How do you like earthquake information we have given to you?
a. $\square$ Excellent
b. $\square$ Good
c. $\square$ Should be OK
d. $\square$ I don't like

j. How much are you interested to learn earthquake by inserting in the curriculum?
a. $\square$ Very much interested
b. $\square$ Interested
c. $\square$ Not interested 